\title{
'SYNTHETIC LIPASE' PRODUCTION FROM A NEWLY ISOLATED SPORIDIOBOLUS PARAROSEUS STRAIN BY
} SUBMERGED FERMENTATION

\author{
Alessandra Smaniotto ${ }^{1}$, Aline Skovronski ${ }^{1}$, Elisandra Rigo ${ }^{1}$, Siu Mui Tsai ${ }^{2}$, Ademir Durrer ${ }^{2}$, Lillian Liva Foltran ${ }^{2}$, Marco \\ Di Luccio $^{3}$, J. Vladimir Oliveira ${ }^{3}$, Débora de Oliveira ${ }^{3}$, Helen Treichel ${ }^{4 *}$
}

${ }^{1}$ Departamento de Engenharia de Alimentos, Universidade Regional Integrada do Alto Uruguai e das Missões, Erechim, RS, Brasil; ${ }^{2}$ Laboratório de Biologia Celular e Molecular, Universidade de São Paulo, Piracicaba, SP, Brasil; ${ }^{3}$ Universidade Federal de Santa Catarina, Departamento de Engenharia Química e de Alimentos, SC, Brasil; ${ }^{4}$ Universidade Federal da Fronteira do Sul, Erechim, RS, Brasil.

Submitted: July 03, 2010; Approved: June 07, 2012.

\begin{abstract}
The lipase produced by a newly isolate Sporidiobolus pararoseus strain has potential catalysis ability for esterification reactions. In order to improve its synthetic activity, this work aimed at optimizing 'synthetic lipase' production by submerged fermentation of a conventional media based on peptone, yeast extract, $\mathrm{NaCl}$ and olive oil using experimental design technique. According to the results obtained in the first experimental design $\left(2^{4-1}\right)$, yeast extract and $\mathrm{NaCl}$ concentrations were tested to further optimization by response surface methodology. The maximum 'synthetic lipase' activity obtained was $26.9 \mathrm{U} / \mathrm{mL}$ in the optimized media (5.0, 6.8, 7.0 and $1.0 \%$ (wt/v) of peptone, yeast extract, $\mathrm{NaCl}$ and olive oil, respectively), representing a 6.36-fold increase compared to the initial medium. The time course of 'synthetic lipase' production in the optimized condition was evaluated in terms of synthetic activity, protease activity, biomass and total carbon and the maximum synthetic activity was observed during the stationary phase of growth.
\end{abstract}

Key words: Sporidiobolus pararoseus; experimental design; 'synthetic lipase’; submerged fermentation.

\section{INTRODUCTION}

Lipases (triacylglycerol hydrolases, EC 3.1.1.3) are a family of hydrolases which act on carboxylic ester bonds. Lipases have recently assumed an important place in the enzyme biotechnology field because they are versatile enzymes which act in a wide range of substrates. They act, by definition, in the organic-aqueous interface, catalyzing the hydrolysis of carboxylic ester bonds and releasing organic acids and alcohols. However, the reverse reaction (esterification) or transesterification reactions can occur in environments with water restriction $(3,14,15,20,29)$.

Lipases are ubiquitous in all types of living organisms and can be obtained from different sources such as microorganisms, animals and plants (3, 20, 29). The enzymes of bacteria and fungi have the greatest potential as industrial

*Corresponding Author. Mailing address: Universidade Federal da Fronteira do Sul, Campus de Erechim, Av. Dom João Hoffman, 313, 99700-000, Erechim, RS, Brazil..; Tel.: +55 54 33217096.; E-mail: helentreichel@gmail.com 
biocatalysts, as they present high synthesis rates, high-yield conversion of substrate to product, great versatility and simplicity in environmental and genetic manipulation of its productive capacity and improved recovery from fermentation broth $(3,20)$.

Microbial lipases are produced mainly by submerged culture (31). A wide variety of culture conditions that stimulate or suppress the production of microbial lipases are described in the literature, and there is no general procedure to improve its production $(15,31)$. The expression of lipolytic proteins is often induced and can be modulated by several parameters (20). Among them, sources of carbon and nitrogen supplied during fermentation are of particular importance, as well as the addition of compounds which can act as inducers, such as lipid carbon sources $(31,37)$. It has been reported that some eukaryotic microorganisms can produce different forms of lipases with different catalytic properties, and production of these biocatalysts were influenced by culture conditions (39).

Hydrolytic and synthetic activities are often used to characterize a lipase catalytic ability, and the former is mostly preferred. However, it has been proposed that synthetic activities of lipases in organic solvents do not correspond to their hydrolytic activities, and not all the lipases were capable of catalyzing synthetic reactions in organic solvents. In order to improve the lipase catalytic ability in organic solvent, the effects on the enzyme production must be studied systematically and the culture condition needs to be optimized (35, 36, 39).

Being an indicator of catalytic ability in organic solvent, synthetic activity of lipase attracts more and more researchers' eyes (39). The production of lipases for use in organic media has advantages such as higher solubility in hydrophobic substrates, shift of thermodynamic equilibrium in favor of synthesis instead of hydrolysis and increased thermo-stability of the enzyme. However, catalytic activities are generally lower than those expressed in water, due to difficulties in homogenization of the catalytic system (22).

'Synthetic lipases' are gaining more attention nowadays because of their potential to catalyze the production of biodiesel, reducing the operational cost associated with the conventional process, as well overcoming problems related to chemical catalysis. As the lipase cost of producing is a major obstacle to the commercialization of the lipase catalyzed process, various attempts have been made to develop cheaper systems $(28,38)$. Besides biodiesel production, many other applications of lipase with synthetic activity have been proposed, such as enantioselective reactions $(6,24)$, synthesis of various esters $(5,21,26)$ and kinetic resolutions of chiral compounds (2).

Till date yeast lipases from Candida rugosa and Candida antarctica stand out as the sources of most commercially available lipase preparations $(17,37)$. At the same time, continuous demand for highly active enzymes with appropriate properties encourages the research for new enzyme sources (17). In a previous work developed by our research group, a number of microorganisms potentially producers of synthetic and hydrolytic lipases were isolated from various sources (13). Here, we report media optimization for maximum 'synthetic lipase' production from a newly isolated strain of Sporidiobolus pararoseus by submerged fermentation of a conventional media.

\section{MATERIALS AND METHODS}

\section{Yeast identification}

Firstly, the strain was incubated in PD medium at $28{ }^{0} \mathrm{C}$ for 24 hours. The yeast DNA was extracted according to the methodology proposed by Stearling (32) and quantified in a spectrophotometer model NanoDrop, ND-1000 (NanoDrop Technologies).

The domain D1/D2 of the 26S rDNA, that provided a similar identification when compared with DNA reassociation, is a quickly and easy methodology for yeast species (18).Using primers NL1 and NL4 $(10,19)$ this region was amplified in a volume of $25 \mu \mathrm{L}$ containing: $2.0 \mu \mathrm{L}$ of DNA; $1.5 \mathrm{mM} \mathrm{MgCl}_{2}$, $0.2 \mathrm{mM}$ of dNTP; $0.2 \mathrm{mM}$ of each primers and $0.2 \mu \mathrm{L}$ of 
Platinum ${ }^{\circledR}$ Taq Polymerase $5 \mathrm{U} / \mu \mathrm{L}$ (Invitrogen). The reactions were performed using a termocycler, model GeneAmp PCR System 9700 (Applied Biosystems) under the following conditions: $94{ }^{\circ} \mathrm{C}$ for $5 \mathrm{~min}$, followed by 33 cycles of $94^{\circ} \mathrm{C}$ for $30 \mathrm{~s}, 52{ }^{\circ} \mathrm{C}$ for $45 \mathrm{~s}$ and $72{ }^{\circ} \mathrm{C}$ for $1 \mathrm{~min}$; and a final extension of $72{ }^{\circ} \mathrm{C}$ for $10 \mathrm{~min}$. Visualization of the amplified DNA was performed by electrophoresis in 1.5\% agarose in $0.5 \mathrm{X}$ TSB buffer and staining with GelRed (Biotium Inc., Hayward, CA), using as molecular standard $2 \mu \mathrm{L}$ of Low Mass 47 DNA Ladder (Invitrogen Technology). The product was purified with the Kit GFX ${ }^{\mathrm{TM}}$ PCR DNA and Gel Band Purification (GE Healthcare), according to the manufacturer's instructions and sequenced in an automatic sequencer ABI PRISM 3100 Genetic Analyzer (Applied Biosystems).

For the construction of the sequence consensus, the programs Phred/Phrap (9) and Consed (12) were used. This sequence was compared with data from GenBank National Center for Biotechnology Information (NCBI) and references sequences $(1,10)$. The global alignment of the sequences and the phylogenetic analysis were performed with the program MEGA version 4.0 (34). Cladistic analyses were constructed with the neighbor joining method (30), using Jukes-Cantor for distance measurement. The confidence levels for the individual branches of the resulting tree were assessed by bootstrap analysis (11), in which 1000 bootstrapped trees were generated from the re-sampled data.

\section{Cell production}

The yeast used in the present study was previously isolated from soybean meal (13). This microorganism was maintained in glycerol at $-80^{\circ} \mathrm{C}$ and potato dextrose agar slants under refrigeration. The propagation was carried out for 3 days at $30^{\circ} \mathrm{C}$ in Petri plates containing a media constituted by potato dextrose agar (PDA) 3.9\% (m/v) and distilled water. The preinoculum was prepared by adding the microorganism from the plate in test tubes containing $10 \mathrm{~mL}$ of PC media (0.5, 0.25 and $0.1 \% \mathrm{~m} / \mathrm{v}$ of tryptone, yeast extract and dextrose, respectively) sterilized at $121^{\circ} \mathrm{C}$ for 15 minutes. The mixture was incubated at $30{ }^{\circ} \mathrm{C}$ for 24 hours. The inoculum was prepared by mixing the pre-inoculum with $90 \mathrm{~mL}$ of sterilized PC media in $250 \mathrm{~mL}$ Erlenmeyer flasks covered with cotton plugs. The flasks were incubated in rotary shaker at $30{ }^{\circ} \mathrm{C}$ and $150 \mathrm{rpm}$ for 24 hours.

\section{Culture conditions}

Fermentation media consisted of peptone, yeast extract, $\mathrm{NaCl}$ and olive oil at different concentrations. Cultivation was carried out in $250 \mathrm{~mL}$ Erlenmeyers flasks covered with cotton plugs in rotary shaker at $30^{\circ} \mathrm{C}$ and $150 \mathrm{rpm}$. The media (90 $\mathrm{mL}$ ) was sterilized at $121{ }^{\circ} \mathrm{C}$ for 15 minutes, cooled and inoculated with the inoculum solution (10\%). After fermentation, samples were collected and filtered through Whatmann qualitative paper. The filtrate was frozen at $-80{ }^{\circ} \mathrm{C}$ for 24 hours and then lyophilized for 48 hours. The resultant solid was considered the crude enzymatic extract and used for analytical assays.

\section{Optimization of lipase production}

The concentration of media components, which could influence 'synthetic lipase' production by Sporidiobolus pararoseus under submerged fermentation, was evaluated. Before optimization, a time course experiment was conducted using the conventional media optimized in a previous work (25). Lipase synthetic activity in a media constituted by 2.0, $0.5,0.5$ and $1.0 \% \mathrm{wt} / \mathrm{v}$ of peptone, yeast extract, $\mathrm{NaCl}$ and olive oil, respectively, was monitored within 168 hours of fermentation at $30{ }^{\circ} \mathrm{C}$ and $150 \mathrm{rpm}$. The media optimization for the production of lipase by $S$. pararoseus was performed at 48 hours of fermentation using the strategy of sequential experimental designs. In the first experimental design, the effects of media components were evaluated using a $2^{4-1}$ fractional design. After statistical analysis, a second experimental design (full $2^{2}$ ) was performed keeping constant peptone and olive oil concentrations (5.0 and $1.0 \% \mathrm{wt} / \mathrm{v}$, respectively). In order to optimize the lipase production, three concentrations of $\mathrm{NaCl}(7.0,8.0$ and $9.0 \% \mathrm{wt} / \mathrm{v})$ were evaluated in triplicate assays, keeping constant the peptone, 
yeast extract and olive oil concentrations (5.0, 6.8 and $1.0 \% \mathrm{wt} / \mathrm{v}$, respectively). Table 1 presents the variables and range of study for the experimental designs performed. The response evaluated in all experiments was lipase synthetic activity.

Table 1. Ranges of factors investigated in the sequential experimental designs

\begin{tabular}{cccc}
\hline & \multicolumn{3}{c}{ First Experimental } \\
Design \\
\cline { 2 - 4 } Level & $\mathbf{- 1}$ & $\mathbf{0}$ & $\mathbf{1}$ \\
\hline Peptone (\%wt/v) & 2 & 5 & 8 \\
Yeast Extract (\%wt/v) & 0 & 1.75 & 3 \\
NaCl (\%wt/v) & 0 & 1.75 & 3 \\
Olive oil (\%wt/v) & 0 & 1 & 2 \\
\hline & \multicolumn{3}{c}{ Second Experimental } \\
& \multicolumn{3}{c}{ Design } \\
\hline Yeast extract (\%wt/v) & 1.2 & 4 & 6.8 \\
\hline $\mathrm{NaCl}(\% \mathrm{wt} / \mathrm{v})$ & 1.2 & 4 & 6.8 \\
\hline
\end{tabular}

\section{Time course of lipase production}

Lipase synthetic activity, protease activity, biomass (dry cellular weight) and total carbon concentration were monitored within 120 hours of fermentation in the optimized condition.

\section{Analytical assays}

Lipase synthetic activity was assayed by alkali titration using oleic acid and ethanol as substrates. A $0.1 \mathrm{~g}$ sample of lyophilized enzyme was added to a 1:2 mixture of oleic acid and ethanol. After incubation in shaker for 40 minutes at $40{ }^{\circ} \mathrm{C}$ and $150 \mathrm{rpm}$, the reaction was interrupted and the products were extracted by the addition of $20 \mathrm{~mL}$ of an acetone/ethanol solution $(1: 1 \mathrm{v} / \mathrm{v})$. The amount of oleic acid consumed was then titrated with $0.02 \mathrm{M} \mathrm{NaOH}$ until $\mathrm{pH} 11$. Reaction blanks were run in the same way, but adding the sample after addition of acetone/ethanol solution. The lipase activities were performed in duplicate. A unit of lipase activity was defined as the amount of enzyme that consumes $1 \mu \mathrm{mol}$ of oleic acid per minute under the assay conditions.

Protease activity was measured by a modified method described elsewhere (4) using azocasein as substrate for proteolytic enzymes. Biomass estimation was determined by OD at $695 \mathrm{~nm}$ (Agilent 8453); a calibration curve was built to correlate OD and dry cellular weight. Total carbon concentration was determined in a Total Organic Carbon Analyzer (TOC-V CSH Shimadzu).

\section{RESULTS AND DISCUSSION}

\section{Yeast identification}

The isolate was identified as Sporidiobolus pararoseus, with $100 \%$ homology, when compared to reference sequences of D1/D2 domain from NCBI (18). Furthermore, a dendrogram analysis also confirmed the identity of isolate W8 with Bootstrap of $97 \%$, when compared to species of S. pararoseus (Fig. 1).

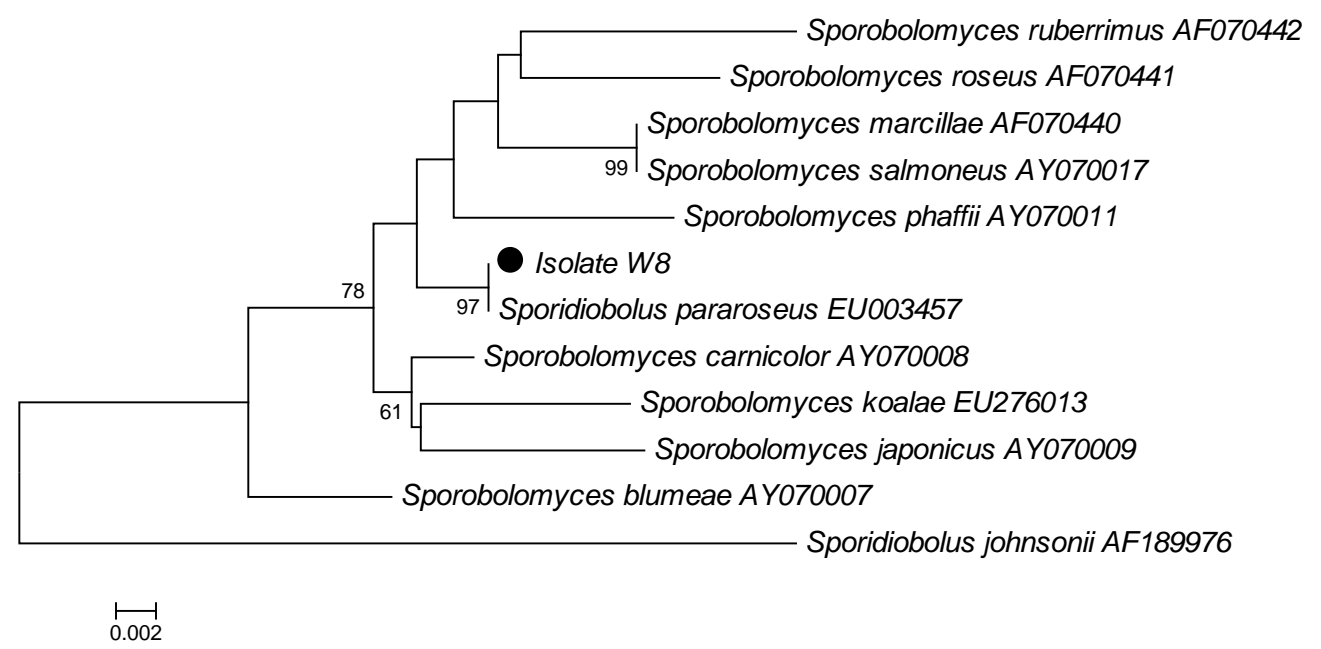

Figure 1. Phylogenetic trees drawn from neighbor-joining analysis based on sequences of the D1/D2 domain, depicting the relationships of Sporidiobolus pararoseus and the novel isolated W8. Bootstrap percentages over 50\% from 1000 bootstrap replicates are shown 


\section{Lipase production optimization}

Before optimization process was carried out, a time course experiment was conducted in a media optimized previously (25). Fig. 1 presents the time course of 'synthetic lipase' production within a 168 hours incubation period. It can be observed that the highest lipase activity $(4.23 \mathrm{U} / \mathrm{mL})$ was obtained after 48 hours of fermentation. In this way, this fermentation time was chosen to perform the sequential experimental design.

Table 2 presents the matrix of the $2^{4-1}$ fractional experimental design performed in the first step of this work with real and coded values for independent variables (peptone, yeast extract, $\mathrm{NaCl}$ and olive oil concentrations) and the response in terms of lipase synthetic activity in 48 hours of fermentation. From Table 2 it can be observed that the highest lipase activity $(7.98 \mathrm{U} / \mathrm{mL})$ was obtained using the highest media components concentrations (run 8). However, lipase activity obtained in this experimental condition was quite similar to that of the central points $(7.05 \pm 0.85 \mathrm{U} / \mathrm{mL}$ - runs 9, 10 and 11). According to Tukey's test, these values showed no significant difference at a 95\% confidence level.

Table 2. Matrix of the first experimental design (coded and real values) with responses in terms of lipase synthetic activity

\begin{tabular}{cccccc}
\hline Run & $\begin{array}{c}\text { Peptone } \\
\text { (\% wt/v) }\end{array}$ & $\begin{array}{c}\text { YE } \\
\text { (\% wt/v) }\end{array}$ & $\begin{array}{c}\text { NaCl } \\
\text { (\% wt/v) }\end{array}$ & $\begin{array}{c}\text { Olive oil } \\
\text { (\% wt/v) }\end{array}$ & LSA (U/mL) \\
\hline 1 & $-1(2)$ & $-1(0)$ & $-1(0)$ & $-1(0)$ & 0.25 \\
2 & $+1(8)$ & $-1(0)$ & $-1(0)$ & $+1(2)$ & 1.16 \\
3 & $-1(2)$ & $+1(3)$ & $-1(0)$ & $+1(2)$ & 2.48 \\
4 & $+1(8)$ & $+1(3)$ & $-1(0)$ & $-1(0)$ & 2.28 \\
5 & $-1(2)$ & $-1(0)$ & $+1(3)$ & $+1(2)$ & 2.46 \\
6 & $+1(8)$ & $-1(0)$ & $+1(3)$ & $-1(0)$ & 1.07 \\
7 & $-1(2)$ & $+1(3)$ & $+1(3)$ & $-1(0)$ & 4.89 \\
8 & $+1(8)$ & $+1(3)$ & $+1(3)$ & $+1(2)$ & 7.98 \\
9 & $0(5)$ & $0(1.75)$ & $0(1.75)$ & $0(1)$ & 7.82 \\
10 & $0(5)$ & $0(1.75)$ & $0(1.75)$ & $0(1)$ & 7.19 \\
11 & $0(5)$ & $0(1.75)$ & $0(1.75)$ & $0(1)$ & 6.14 \\
\hline
\end{tabular}

For a more consistent analysis of these results, the data obtained were tabulated and analyzed using the software Statistica $^{\circledR}$, module of Experimental Design. We could observe that, with a $90 \%$ confidence level, yeast extract and $\mathrm{NaCl}$ presented significant positive effects on lipase synthetic activity. The other factors also presented positive effects, which were not significant considering the same confidence level.

Generally, microorganisms provide high yields when organic nitrogen sources are used, such as peptone and yeast extract. Yeast extract is one of the most important nitrogen sources for high level lipase production by different microorganisms. Besides this role, it supplies vitamins and trace elements for their growth and increases their lipase production (8). Peptone and yeast extract were found to have positive effects on hydrolytic lipase production by Rhizopus arrhizus (27). Peptone was also found to efficiently improve the production of extracellular lipase by many other researchers. In the production whole-cell synthetic lipase by Rhizopus chinensis in SSF, the supplementation of $2.0 \%(\mathrm{w} / \mathrm{w})$ of peptone gave the highest activity (16,855 U/Kg substrate). According to these authors, the enhanced synthetic activity with whole-cell lipase is probably ascribed to some co-factors or amino-acids contained in peptone which accidentally match $R$. chinensis physiological requirements for WCSL biosynthesis (33). In the optimization of submerged fermentation media for the production of synthetic membranebound lipase from Rhizopus chinensis, the authors found that peptone concentration was the most important factor influencing lipase production, followed by olive oil concentration (39).

Many researchers have published their results on effects 
of oils in enhancing lipase synthetic and hydrolytic activities (33). However, a few authors have produced high yields of hydrolytic lipases in the absence of fats and oils (31). In a work evaluating the influence of the presence of different lipid compounds on the production of different lipases (intracellular, extracellular and membrane-bound) by Thermus thermophillus in submerged fermentation, it has been shown that the presence of olive oil improved the production of intracellular and membrane-bound lipases, but not extracellular lipases (7).

The salinity was found to be a critical factor on the production of hydrolytic lipase by a marine isolated Pseudomonas sp. strain. In the absence of sodium chloride, only traces of enzyme were produced and no considerable microorganism growth was observed. The lipase production reached the highest value when the production media contained $1.5 \% \mathrm{NaCl}(16)$.

Based on the results obtained from statistical analysis, yeast extract and $\mathrm{NaCl}$ concentrations have been selected as factors to be studied in a full $2^{2}$ experimental design. Although peptone and olive oil have not presented significant effect at 95\% confidence level, the highest responses were observed on the highest levels for all factors and on central points. In this way, in full $2^{2}$ experimental design, peptone and olive oil concentrations were kept at their respective central point values (5.0 and $1.0 \% \mathrm{wt} / \mathrm{v}$, respectively), while the levels of the other variables were moved upward.

Table 3 presents the matrix of the $2^{2}$ full experimental design accomplished in this step with real and coded values for the independent variables and the response in terms of lipase activity. From this table it can be observed that the highest lipase synthetic activity (19.13 U/mL) was obtained using the highest media components concentrations (run 4).

Table 3. Matrix of the second experimental design (coded and real values) with responses in terms of lipase synthetic activity

\begin{tabular}{cccc}
\hline \multirow{2}{*}{ Run } & $\begin{array}{c}\text { YE } \\
\text { wt/v) }\end{array}$ & NaCl (\% wt/v) & LA (U/mL) \\
\hline 1 & $-1(1.2)$ & $-1(1.2)$ & 6.03 \\
2 & $+1(6.8)$ & $-1(1.2)$ & 5.10 \\
3 & $-1(1.2)$ & $+1(6.8)$ & 13.00 \\
4 & $+1(6.8)$ & $+1(6.8)$ & 19.13 \\
5 & $0(4)$ & $0(4)$ & 11.07 \\
6 & $0(4)$ & $0(4)$ & 7.79 \\
7 & $0(4)$ & $0(4)$ & 9.72 \\
\hline
\end{tabular}

The statistical analysis of the second experimental design data revealed that $\mathrm{NaCl}$ concentration exhibited positive significant effect $(\mathrm{p}<0.05)$ on lipase production. Yeast extract concentration and the linear interaction between yeast extract and $\mathrm{NaCl}$ concentrations showed no significant effect at $95 \%$ confidence level.

Equation 1 presents the coded optimized model for 'synthetic lipase' production as a function of yeast extract and $\mathrm{NaCl}$ concentrations. The ANOVA analysis for lipase activity showed high correlation coefficient $(\mathrm{R}=0.94)$ and a good performance on the F-test for regressions. The model generated a response surface depicted in Fig. 2.

Lipase activity $(U / m L)=10.26+1.30$.yeast extract $(L)+5.25 . \mathrm{NaCl}(L)$ +1.76 .yeast extract $(L) . \mathrm{NaCl}(L)$

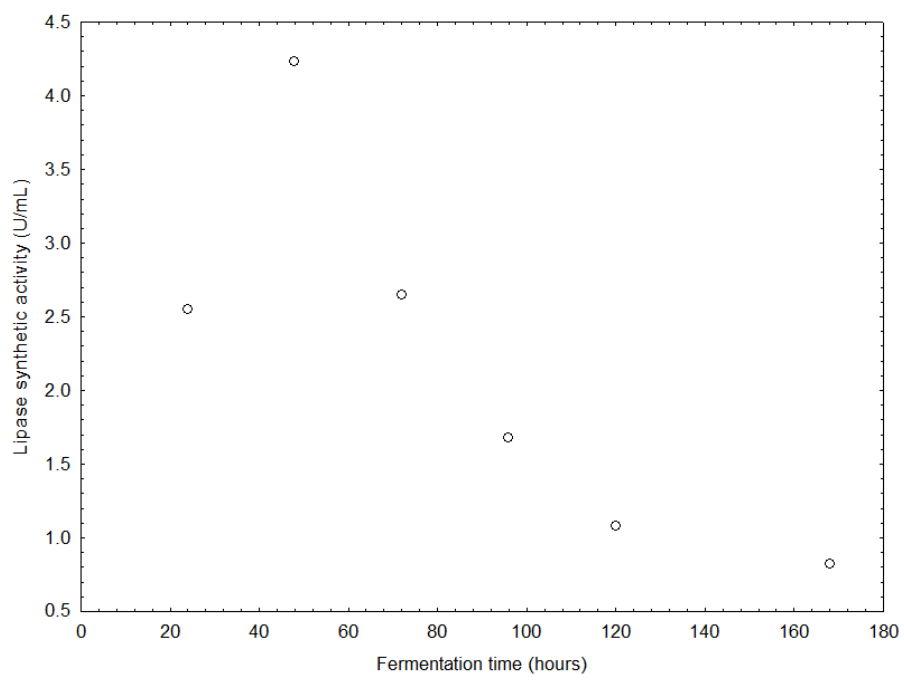

Figure 2. Time course of 'synthetic lipase' production within 168 hours of fermentation in a media composed by 2.0, 0.5, 0.5 and $1.0 \%(\mathrm{wt} / \mathrm{v})$ of peptone, yeast extract, $\mathrm{NaCl}$ and olive oil, respectively

After analyzing the results obtained in the second experimental design, the next step towards optimizing lipase production was to increase $\mathrm{NaCl}$ concentration. Peptone and olive oil concentrations were kept at the same levels and yeast extract was fixed at +1 level $(6.8 \% \mathrm{wt} / \mathrm{v})$ of the full $2^{2}$ design. 


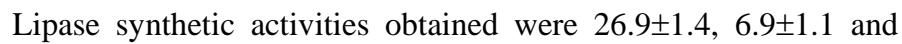
$0.0 \pm 0.0 \mathrm{U} / \mathrm{mL}$ for 7.0, 8.0 and $9.0 \%(\mathrm{wt} / \mathrm{v})$, respectively. Tukey’s test has been performed and the different concentrations showed significant difference among each other at 95\% level of confidence. This result shows that 'synthetic lipase' production is inhibited at higher $\mathrm{NaCl}$ concentrations.

Therefore, the optimized condition for 'synthetic lipase' production from $S$. pararoseus by submerged fermentation of a conventional media was 5.0, 6.8, 7.0 and $1.0 \%(\mathrm{wt} / \mathrm{v})$ of peptone, yeast extract, $\mathrm{NaCl}$ and olive oil concentrations, respectively. The maximum lipase synthetic activity obtained in this experimental design was $26.9 \mathrm{U} / \mathrm{mL}$ at 48 hours of fermentation.

In the study of the production of 'whole-cell synthetic lipase' from Rhizopus chinensis by solid-state fermentation using a combined wheat flour and bran substrate, the maximum synthetic activity of $24,447 \mathrm{U} / \mathrm{kg}$ substrate was reached by selecting a moisture content of $70 \%$, initial $\mathrm{pH}$ of 6.5 , supplementation of peptone $(2 \%, \mathrm{w} / \mathrm{w})$ as additional nitrogen source and olive oil (2\%, $\mathrm{v} / \mathrm{w}$ ) as inducer; which represented a 15.27-fold increase of lipase synthetic activity compared to the initial media (33).

The factors agitation, inoculums, maltose, olive oil and
$\mathrm{K}_{2} \mathrm{PO}_{4}$ concentrations, $\mathrm{pH}$ and fermentation volume in the production of 'synthetic lipase' from Rhizopus chinensis by submerged fermentation were studied. Under optimal conditions, the experimental result was 13,875 U/L, which $120 \%$ improved compared with the un-optimized condition (35).

The optimized media composed by maltose, peptone, $\mathrm{MgSO}_{4} \cdot 7 \mathrm{H}_{2} \mathrm{O}$ and $\mathrm{K}_{2} \mathrm{HPO}_{4}$ for whole-cell synthetic lipase production in submerged fermentation by $R$. chinensis enhanced in $61.5 \%$ the synthetic activity of the membrane-bound lipase produced (470 U/g dry cells $_{\text {) }}$ (39). A ‘synthetic lipase’ activity of 694 $\mathrm{U} / \mathrm{g}_{\text {dry cells }}$ was obtained when $20 \mathrm{~g} / \mathrm{L}$ soybean oil was added to the previous media (36).

\section{Time course of lipase production}

Lipase synthetic activity, biomass (dry cellular weight) and total carbon concentration profile for lipase production in the optimized media is given in Fig. 3. From this profile it can be observed that the highest lipase synthetic activity was obtained in 72 hours of fermentation using the optimized media. It was not observed protease activity during the fermentation according to the measurements.

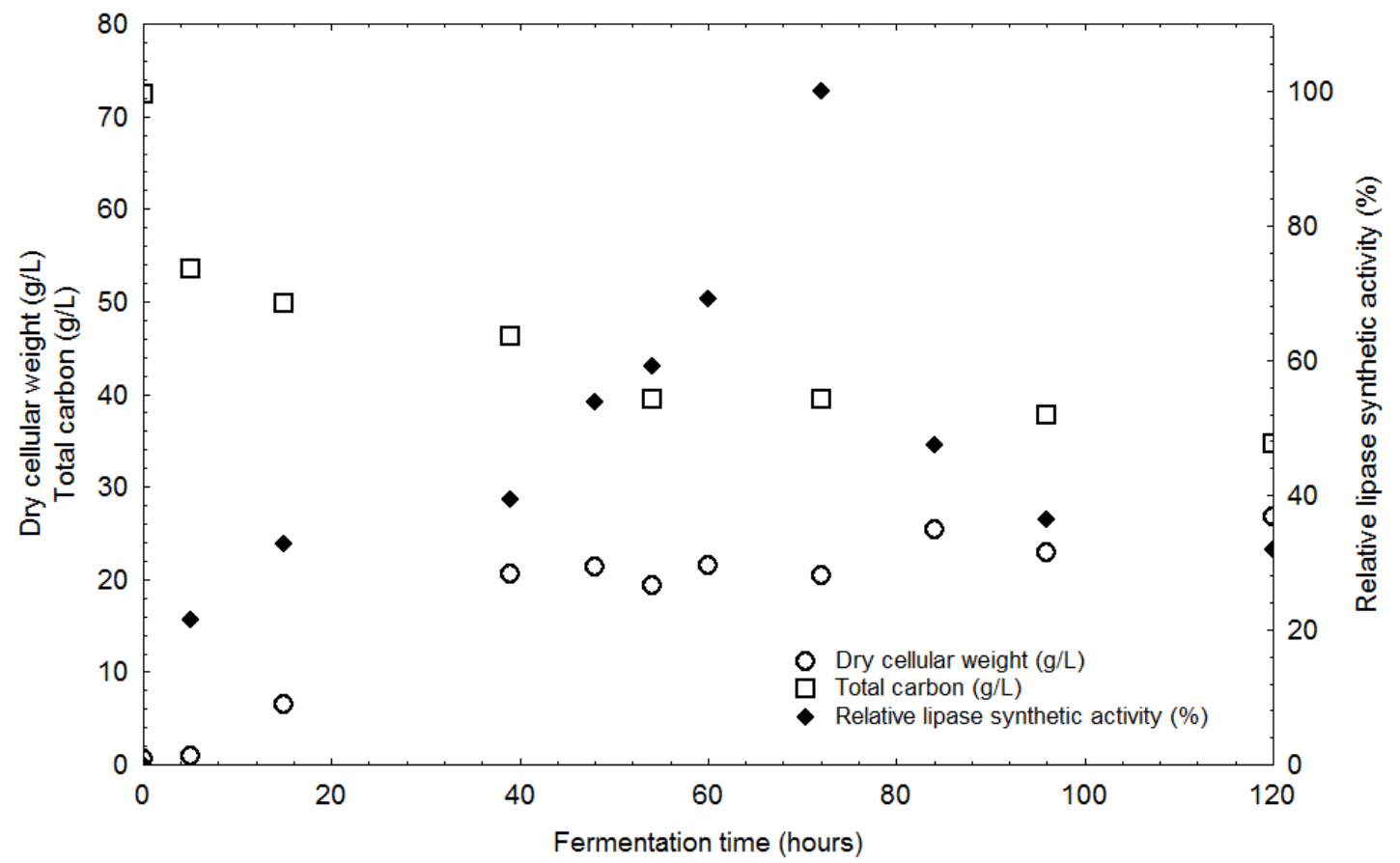

Figure 3. Time course of 'synthetic lipase' production, carbon consumption and cellular growth within 120 hours in the optimized condition 
As described for most extracellular lipases, the maximum lipase activity was recorded in the stationary phase. Result obtained here is in accordance with hydrolytic lipase production in submerged fermentation by Clostridium tetanomorphum (7 U/mL) (23), Pseudomonas sp. (750 U/mL) (16), Trichosporon asahii (104 U/mL) (17) and Rhizopus arrhizus (2.98 U/mL) (27) and 'synthetic lipase' production in SSF by Rhizopus chinensis (24,447 U/kg) (33).

It can be also observed that there is a tendency of stabilization of the microorganism growth while total carbon keeps slightly decreasing. The maximum rate of carbon consumption in lower fermentation time coincides with the maximum rate of cellular growth, which means that most of the carbon present in the media was consumed for the microorganism growth.

\section{CONCLUSION}

The isolate Sporidiobolus pararoseus strain yielded good results for the production of 'synthetic lipase' by submerged fermentation by a conventional medium. The optimized condition for 'synthetic lipase' production was determined as 5.0, 6.8, 7.0 and $1.0 \%(\mathrm{w} / \mathrm{v})$ of peptone, yeast extract, $\mathrm{NaCl}$ and olive oil, respectively, at $30{ }^{\circ} \mathrm{C}$ and $150 \mathrm{rpm}$ and $10 \%$ of inoculum. The optimized media yielded a lipase synthetic activity of $26.9 \mathrm{U} / \mathrm{mL}$ in 72 hours of fermentation, a 6.36-fold increase compared to the non-optimized media.

\section{ACKNOWLEDGEMENTS}

The authors thank CAPES and CNPq for the financial support of this work and scholarships.

\section{REFERENCES}

1. Bai, F.Y.; Zhao, J.H.; Takashima, M.; Jia, J.H.; Boekhout, T.; Nakase T. (2002). Reclassification of the Sporobolomyces roseus and Sporidiobolus pararoseus complexes, with the description of Sporobolomyces phaffii sp. nov. Int. J. Sys. Evol. Microbiol. 52: 2309-2314.
2. Ball, A.J.; Corr, S.; Micklefield, J. (2009). Lipase-catalysed kinetic resolutions of secondary alcohols in pressurized liquid hydrofluorocarbons. Tetrahedron Lett. 50: 3543-3546.

3. Bon, E.P.S.; Ferrara, M.A.; Corvo, M.L. (2008). Enzimas em biotecnologia. Rio de Janeiro: Interciência.

4. Charney, J.E.; Tomarelli, R.M.A. (1947). Colorimetric method for the determination of the proteolytic activity of duodenal juice. J. Biol. Chem. 171: 501-505.

5. Cramer, J.F.; Duenholm, M.S.; Nielsen, S.B.; Pedersen, D.S.; Wimmer, R.; Pedersen, L.H. (2007). Controlling the degree of esterification in lipase catalysed synthesis of xylitol fatty acid esters. Enzyme Microb. Technol. 41: 346-352.

6. D’Antona, N.; Lambusta, D.; Nicolosi, G.; Bovicelli, P. (2008). Preparation of regioprotected morins by lipase-catalysed transesterification. J. Mol. Catal. B Enz. 5253: 78-81.

7. Deive, F.J.; Carvalho, E.; Pastrana, L.; Rúa, M.L.; Longo, M.A.; Sanroman, M.A. (2009). Strategies for improving extracellular lipolytic enzyme production by Thermus thermophilus HB27. Bioresour. Technol. 100: 3630-3637.

8. Ebrahimpour, A.; Rahman, R.N.Z.R.A.; Ch'ng, D.H.E.; Basri, M.; Salleh, A.B. (2008). A modeling study by response surface methodology and artificial neural network on culture parameters optimization for thermostable lipase production from a newly isolated thermophilic Geobacillus sp. strain ARM. BMC Biotechnol. 8: 96-111.

9. $\quad$ Ewing, B.; Hillier, L.; Wendl, M.C. (1998). Base-Calling of Automated Sequencer Traces Using Phred.?I. Accuracy? Assessment. Genome Res. 8: 175-185.

10. Fell, J.W.; Boekhout, T.; Fonseca, A.; Scorzetti, G.; Statzell-Tallman, A. (2000). Biodiversity and systematics of basidiomycetous yeasts as determined by large-subunit rDNA D1/D2 domain sequence analysis. Int. J. Sys. Evol. Microbiol. 3: 1351-1371.

11. Fell, J.W.; Boekhout, T.; Fonseca, A.; Scorzetti, G.; Statzell-Tallman, A. (2000). Biodiversity and systematics of basidiomycetous yeasts as determined by large-subunit rDNA D1/D2 domain sequence analysis. Int. J. Sys. Evol. Microbiol. 3: 1351-1371.

12. Felsenstein, J. (1985). Confidence limits on phylogenies: an approach using the bootstrap. Evol. 39: 783-791.

13. Gordon, D.; Abajian, C.; Grenn, P. (1998). Consed: A Graphical Tool for Sequence? Finishing. Genome Res. 8: 195-202.

14. Griebler, N.; Polloni, A.; Remonatto, D.; Arbter, F.; Vardanega, R.; Cechet, J.; Di Luccio, M.; Oliveira, D.; Treichel, H.; Cansian, R.; Rigo, E.; Ninow, J. (2009). Isolation and screening of lipase-producing fungi with hydrolytic activity. Food Bioproc. Technol., DOI 10.1007/s11947008-0176-5, in press.

15. Hasan, F.; Shah, A.A.; Hameed, A. (2006). Industrial applications of microbial lipases. Enzyme Microbial Technol. 39: 235-251.

16. Kademi, A.; Leblane, D.; Houde, A. (2004). Lipases. In: Pandey A. 
Concise Encyclopedia of Bioresource Technology. New York: The Haworth Press Inc., 552-561.

17. Kiran, G.S.; Shanmugnhapriya, S.; Jayalakshmi, J.; Selvin, J.; Gandhimathi, R.; Sivaramakrishnan, S.; Arunkumar, M.; Thangavelu, T.; Natarajaseenivasan, K. (2008). Optimization of extracellular psychrophilic alkaline lipase produced by marine Pseudomonas sp. (MSI057). Bioproc. Biosys. Eng. 31: 483-492.

18. Kumar, S.; Gupta, R. (2008). An extracellular lipase from Trichosporon asahii MSR 54: Medium optimization and enantioselective deacetylation of phenyl ethyl acetate. Process Biochem. 43: 1054-1060.

19. Kurtzman, C.P.; Robnett, C.J. (1998). Identification and phylogeny of ascomycetous yeasts from analysis of nuclear large sub- unit 26S ribosomal DNA partial sequences. Antonie van Leeuwenhoek. 3: 331371.

20. Kurtzman, C.P. (2006). Yeast species recognition from gene sequence analyses and other molecular methods. Mycoscie. 47: 65-71.

21. Lotti, M.; Alberghina, L. (2007). Lipases: Molecular Structure and Functions. In:Polaina $\mathrm{J}$ and MacCabe A P. Industrial Enzymes: Structure, Function and Applications. Dordrecht:Springer, 263-282.

22. Nyaradzo, T.L.; Chingorimbo-Murefu, A.; Riva, S.; Burton, S.G. (2009). Lipase-catalysed synthesis of esters of ferulic acid with natural compounds and evaluation of their antioxidant properties. J. Mol. Catal. B Enz. 56: 277-282.

23. Persson, M.; Mladenoska, I.; Wehtje, E.; Adlercreutz, P. (2002). Preparation of lipases for use in organic solvents. Enzyme Microb. Technol. 31: 833-841.

24. Petersen, M.; Daniel, R. (2006). Purification and characterization of an extracellular lipase from Clostridium teatnomorphum. World $\mathrm{J}$. Microbiol. Biotechnol. 22: 431-435.

25. Pilissão, C.; Carvalho, P.O.; Nascimento, M.G. (2009). Enantioselective acylation of (RS)-phenylethylamine catalysed by lipases. Process Biochem. 44: 1352-1357.

26. Pinheiro, T.F.; Menoncin, S.; Domingues, N.M.; Oliveira, D.; Treichel, H.; Di Luccio, M.; Freire, D.M. (2008). Production and partial characterization of lipase from Penicillium verrucosum obtained by submerged fermentation of conventional and industrial media. Ciência e Tecnologia de Alimentos. 28: 444-450.

27. Pires-Cabral, P.; Fonseca, M.M.R.; Ferreira-Dias, S. (2007). Modelling the production of ethyl butyrate catalysed by Candida rugosa lipase immobilised in polyurethane foams. Biochem. Eng. J. 33: 148-158.

28. Rajendran, A.; Thangavelu, V. (2009). Statistical experimental design for evaluation of medium components for lipase production by Rhizopus arrhizus MTCC 2233. LWT - Food Sci. Technol. 42: 985-992.

29. Ranganathan, S.V.; Narasimhan, S.L.; Muthukumar, K. (2008). An overview of enzymatic production of biodiesel. Bioresour. Technol. 99; 3975-3981.

30. Reis, P.; Holmberg, K.; Watzke, H.; Leser, M.E.; Miller, R. (2009). Lipases at interfaces: A review. Adv. Colloid Interface Sci. 147-148: 237-250.

31. Saitou, N.; Nei, M. (1987). The neighbor-joining method: a new method for reconstructing phylogenetic trees. Mol. Biol. Evol. 4: 406-425.

32. Sharma, R.; Chisti, Y.; Banerjee, U.C. (2001). Production, purification, characterization, and applications of lipases. Biotechnol. Adv. 19: 627662.

33. Stearling D. (2003). DNA extraction from Fungi, Yeast and Bacteria. PCR Protocols. Humana Press.

34. Sun, S.Y.; Xu, Y. (2008). Solid-state fermentation for 'whole-cell synthetic lipase' production from Rhizopus chinensis and identification of the functional enzyme. Process Biochem. 43: 219-224.

35. Tamura, K.; Dudley, J.; Nei, M.; Kumar, S. (2007). MEGA4: Molecular Evolutionary Genetics Analysis (MEGA) software version 4.0. Mol. Biol. Evol. 24: 1596-1599.

36. Teng, Y.; Xu, Y. (2008). Culture condition improvement for whole-cell lipase production in submerged fermentation by Rhizopus chinensis using statistical method. Bioresour. Technol. 99: 3900-3907.

37. Teng, Y.; Xu, Y.; Wang, D. (2009). Production and regulation of different lipase activities from Rhizopus chinensis in submerged fermentation by lipids. J. Mol. Catal. B Enz. 57: 292-298.

38. Treichel, H.; Oliveira, D.; Mazutti, M.A.; Di Luccio, M.; Oliveira, J.V. (2010). A review on microbial lipases production. Food Bioproc. Technol. 3: 182-196.

39. Vieira, A.P.; Silva, M.A.P.; Langone, M.P. (2006). Biodiesel production via esterification reactions catalysed by lipase. Latin Am. Appl. Res. 36: 283-288.

40. Wang, D.; Xu, Y.; Shan, T. (2008). Effects of oils and oil-related substrates on the synthetic activity of membrane-bound lipase from Rhizopus chinensis and optimization of the lipase fermentation media. Biochem. Eng. J. 41: 30-37. 